\title{
The "One-Two Punch" of Isoprenoids to Inflammation
}

\author{
Huanbiao Mo* \\ Department of Nutrition and Food Sciences, Texas Woman's University, Denton, TX 76204, USA
}

A large body of evidence from recent studies has shown that tocotrienols, the vitamin E molecules with an unsaturated farnesyl side chain, have potential in the prevention and/or treatment of cancer, metabolic syndrome, obesity, diabetes, osteoporosis, and neurodegeneration [1]. These activities of tocotrienols may converge on the emerging finding that tocotrienols suppress the activation of nuclear factor kappa $\mathrm{B}(\mathrm{NF \kappa B})$, a major mediator in chronic inflammation that is gaining recognition as one of the main mechanisms underlying these chronic diseases. Tocotrienol-mediated inhibition of $N F \kappa B$ DNA binding activity or suppression of tumor necrosis factor $\alpha$ - and lipopolysaccharide-induced NFKB expression has been demonstrated in human breast cancer cells [2,3], colon carcinoma cells [4], malignant melanoma cells [5], pancreatic cancer cells [6], gastric cancer cells [7], metastatic oral cancer cells [8], adipocytes [9], and macrophages [10]. Moreover, the in vitro NFkB-suppressive activity of tocotrienols was borne out in gastric cancer [7] and pancreatic cancer [11] in nude mice. Readers are referred to recent reviews [12-14] for more details on the anti-inflammatory activity of tocotrienols.

A closer examination of the NFkB-suppressive activity of tocotrienols revealed a more fundamental biological activity of tocotrienols; NFkB suppression may be a secondary effect of tocotrienolmediated down-regulation of another biochemical pathway that is ubiquitous in virtually all eukaryotic cells: the mevalonate pathway [15]. The mevalonate pathway operating in sterologenic tissues provides - in addition to cholesterol that is an essential component of cell membrane and a precursor to vitamin $\mathrm{D}$, bile acids and steroid hormones-essential intermediates including farnesyl- and geranylgeranyl- pyrophosphates for the post-translational prenylation of growth-related proteins such as Ras and nuclear lamins and N-linked glycosylation of insulin-like growth factor receptor I. Most importantly, prenylated Ras activates NFאB [16].

The rate-limiting enzyme in the mevalonate pathway, 3-hydroxy3-methylglutaryl coenzyme A (HMG CoA) reductase, is under a multivalent regulation consisting of sterol-mediated transcriptional feedback inhibition and a non-sterol-mediated post-transcriptional down-regulation. Tocotrienols suppress HMG CoA reductase at both transcriptional and post-transcriptional levels [17] and consequently, deplete the pool of prenyl pyrophosphates required for the prenylation of Ras and inactivate NFkB. Ahn et al. showed that tocotrienol-mediated ablation of $\mathrm{NF \kappa B}$ activity was reversed by supplemental mevalonate, the product of the reaction catalyzed by HMG CoA reductase [15], establishing mevalonate deprivation as the primary cause for $\mathrm{NFKB}$ inactivation.

Tocotrienols may represent a broad class of isoprenoids encompassing approximately 23,000 mevalonate-derived end-products of plant secondary metabolism. Isoprenoids can be classified based on the number of isoprene units they contain, e.g. monoterpene $(2 \mathrm{x})$, sesquiterpene $(3 \mathrm{x})$, diterpene $(4 \mathrm{x})$, triterpene $(6 \mathrm{x})$ and polyterpene (Nx) [18]. In addition to these "pure" isoprenoids, the "mixed" isoprenoids including the tocotrienols have non-mevalonate-derived moieties. Assorted isoprenoids have a wide spectrum of functions in the plant kingdom, ranging from growth regulation to insect attraction, pollination assistance, and pest resistance. Fruits, vegetables and grains are the main sources of dietary isoprenoids.

The HMG CoA reductase-suppressive activity is extensively observed among isoprenoids [19]. It is therefore no coincidence that a number of isoprenoids under investigation also suppress NFkB activity. The monoterpene limonene inhibited NFkB activation in human HL60 clone 15 leukemia cells [20] while an oxidative product of limonene, perillyl alcohol, suppressed NFkB in B-lymphoma cells [21]. A third monoterpene, geraniol, suppressed 12-O-tetradecanoyl phorbol-13-acetate (TPA)-induced inflammatory responses and upregulation of $\mathrm{NF \kappa B}$ and $\mathrm{COX}-2$ in mice [22]. A sesquiterpene $\beta$-ionone inhibited tumor necrosis factor-related apoptosis-inducing ligand (TRAIL)-induced NFkB activation in human HepB3 and HepG2 hepatocellular carcinoma cells [23]. Various sesquiterpene lactones blocked NFkB activity [24]. Diterpene coronarin D suppressed NFkB activation in human KBM-5 chronic myeloid leukemia and A293 embryonic kidney carcinoma cells [25]. Garcinol, a polyisoprenylated benzophenone, inhibited the activation of NFאB in human BxPC-3 and Panc-1 pancreatic cancer cells [26] and squamous cell carcinoma of the head and neck [27]. Lastly, a triterpene lupeol suppressed TPAinduced activation of NFKB in CD-1 mice [28].

More support for the mevalonate-inflammation connection is drawn from studies with the statins, competitive inhibitors of HMG CoA reductase, and protein prenyl transferase inhibitors showing their parallel impacts on NFkB. Simvastatin inhibited NFkB activation in human COLO 205 colon cancer cells [29], squamous cell carcinoma SCC4 cells and KBM-5 cells [30]. Statins also suppressed the tumor necrosis factor $\alpha-[31]$ and receptor activator of NFKB ligand (RANKL) - [32] induced activation of NFKB in RAW 264.7 macrophages. C-reactive protein-induced $\mathrm{NF \kappa B}$ activation was inhibited by simvastatin in human umbilical vein endothelial cells; reminiscent of the findings by Ahn et al. with tocotrienols [15], mevalonate attenuated the simvastatin effect on NFKB [33]. Consequent to Ras inactivation [34], farnesyl transferase inhibitors FTI-276 and SCH 66336 suppressed NFkB activation in rheumatoid arthritis synovial fibroblasts [35], human Jurkat T-cell lymphoma cells, H1299 lung adenocarcinoma cells, MCF-7 breast adenocarcinoma cells, and A293 embryonic kidney cells [34].

By depleting mevalonate and consequently suppressing NFKB activity, isoprenoids and most prominently tocotrienols may deliver a "one-two punch" to inflammation. The omnipresence of the mevalonate pathway and the critical role of inflammation in chronic disorders suggest that dietary isoprenoids warrant further investigation for their potential roles in the prevention and managing of chronic diseases.

*Corresponding author: Huanbiao Mo, Department of Nutrition and Food Sciences, Texas Woman's University, Denton, TX 76204, USA, Tel: 940-898-2712; E-mail: hmo@mail.twu.edu

Received August 24, 2013; Accepted August 24, 2013; Published August 26 2013

Citation: Mo H (2013) The "One-Two Punch" of Isoprenoids to Inflammation. J Nutr Disorders Ther 3: e109. doi:10.4172/2161-0509.1000e109

Copyright: (c) 2013 Mo H. This is an open-access article distributed under the terms of the Creative Commons Attribution License, which permits unrestricted use, distribution, and reproduction in any medium, provided the original author and source are credited. 


\section{References}

1. Tocotrienols: vitamin E beyond tocopherols (2013) In: Tan B, Watson RR Preedy VR (Eds.), (2ndedn), Boca Raton, FL: CRC Press, 2013.

2. Loganathan R, Selvaduray KR, Nesaretnam K, Radhakrishnan AK (2013) Tocotrienols promote apoptosis in human breast cancer cells by inducing poly(ADP-ribose) polymerase cleavage and inhibiting nuclear factor kappa-B activity. Cell Prolif 46: 203-213.

3. Shah SJ, Sylvester PW (2005) Gamma-tocotrienol inhibits neoplastic mammary epithelial cell proliferation by decreasing Akt and nuclear factor kappaB activity. Exp Biol Med (Maywood) 230: 235-241.

4. Xu WL, Liu JR, Liu HK, Qi GY, Sun XR, et al. (2009) Inhibition of proliferation and induction of apoptosis by gamma-tocotrienol in human colon carcinoma HT-29 cells. Nutrition 25: 555-566.

5. Chang PN, Yap WN, Lee DT, Ling MT, Wong YC et al. (2009) Evidence of gamma-tocotrienol as an apoptosis-inducing, invasion-suppressing, and chemotherapy drug-sensitizing agent in human melanoma cells. Nutr Cance 61: $357-366$

6. Husain K, Francois RA, Yamauchi T, Perez M, Sebti SM, et al. (2011) Vitamin $\mathrm{E} \delta$-tocotrienol augments the antitumor activity of gemcitabine and suppresses constitutive NF-KB activation in pancreatic cancer. Mol Cancer Ther 10: 23632372.

7. Manu KA, Shanmugam MK, Ramachandran L, Li F, Fong CW, et al. (2012) First evidence that $\hat{I}^{3}$-tocotrienol inhibits the growth of human gastric cancer and chemosensitizes it to capecitabine in a xenograft mouse model through the modulation of NF-îم ${ }^{\circ} \mathrm{B}$ pathway. Clin Cancer Res 18: 2220-2229.

8. Kani K, Momota Y, Harada M, Yamamura Y, Aota K, et al. (2013) y-tocotrieno enhances the chemosensitivity of human oral cancer cells to docetaxel through the downregulation of the expression of NF-KB-regulated anti-apoptotic gene products. Int J Oncol 42: 75-82.

9. Matsunaga T, Shoji A, Gu N, Joo E, Li S, et al. (2012) Y-Tocotrienol attenuates TNF-a-induced changes in secretion and gene expression of MCP-1, IL-6 and adiponectin in 3T3-L1 adipocytes. Mol Med Rep 5: 905-909.

10. Wang Y, Jiang Q (2013) Y-Tocotrienol inhibits lipopolysaccharide-induced interlukin- 6 and granulocyte colony-stimulating factor by suppressing C/EBP and NF-KB in macrophages. J Nutr Biochem 24: 1146-1152.

11. Kunnumakkara AB, Sung B, Ravindran J, Diagaradjane $P$, Deorukhkar A, et al. (2010) \{Gamma\}-tocotrienol inhibits pancreatic tumors and sensitizes them to gemcitabine treatment by modulating the inflammatory microenvironment Cancer Res 70: 8695-8705.

12. Kaileh M, Sen R (2010) Role of NF-kappaB in the anti-inflammatory effects of tocotrienols. J Am Coll Nutr 29: 334S-339S.

13. Nesaretnam K, Meganathan $P$ (2011) Tocotrienols: inflammation and cancer. Ann N Y Acad Sci 1229: 18-22.

14. Kannappan R, Gupta SC, Kim JH, Aggarwal BB (2012) Tocotrienols fight cancer by targeting multiple cell signaling pathways. Genes Nutr 7: 43-52.

15. Ahn KS, Sethi G, Krishnan K, Aggarwal BB (2007) Gamma-tocotrienol inhibits nuclear factor-kappaB signaling pathway through inhibition of receptorinteracting protein and TAK1 leading to suppression of antiapoptotic gene products and potentiation of apoptosis. J Biol Chem 282: 809-820.

16. Norris JL, Baldwin AS Jr (1999) Oncogenic Ras enhances NF-kappaB transcriptional activity through Raf-dependent and Raf-independent mitogenactivated protein kinase signaling pathways. J Biol Chem 274: 13841-13846.

17. Song BL, DeBose-Boyd RA (2006) Insig-dependent ubiquitination and degradation of 3-hydroxy-3-methylglutaryl coenzyme a reductase stimulated by delta- and gamma-tocotrienols. J Biol Chem 281: 25054-25061.

18. Elson CE, Peffley DM, Hentosh P, Mo H (1999) Isoprenoid-mediated inhibition of mevalonate synthesis: potential application to cancer. Proc Soc Exp Biol Med 221: 294-311.
9. Mo H, Elson CE (2004) Studies of the isoprenoid-mediated inhibition of mevalonate synthesis applied to cancer chemotherapy and chemoprevention. Exp Biol Med (Maywood) 229: 567-585

20. Hirota R, Roger NN, Nakamura H, Song HS, Sawamura M, et al. (2010) Antiinflammatory effects of limonene from yuzu (Citrus junos Tanaka) essential oil on eosinophils. J Food Sci 75: H87-92.

21. Berchtold CM, Chen KS, Miyamoto S, Gould MN (2005) Perillyl alcohol inhibits a calcium-dependent constitutive nuclear factor-kappaB pathway. Cancer Res 65: 8558-8566

22. Khan AQ, Khan R, Qamar W, Lateef A, Rehman MU, et al (2013) Geranio attenuates 12-O-tetradecanoylphorbol-13-acetate (TPA)-induced oxidative stress and inflammation in mouse skin: possible role of p38 MAP Kinase and NF-kB. Exp Mol Pathol 94: 419-429.

23. Kim MO, Moon DO, Kang $\mathrm{CH}$, Kwon TK, Choi YH, et al. (2010) beta-lonone enhances TRAIL-induced apoptosis in hepatocellular carcinoma cells through Sp1-dependent upregulation of DR5 and downregulation of NF-kappaB activity. Mol Cancer Ther 9: 833-843.

24. Siedle B, García-Piñeres AJ, Murillo R, Schulte-Monting J, Castro V, et al. (2004) Quantitative structure-activity relationship of sesquiterpene lactones as inhibitors of the transcription factor NF-kappaB. J Med Chem 47: 6042-6054.

25. Kunnumakkara AB, Ichikawa $H$, Anand $P$, Mohankumar CJ, Hema PS, et al. (2008) Coronarin D, a labdane diterpene, inhibits both constitutive and inducible nuclear factor-kappa B pathway activation, leading to potentiation of apoptosis, inhibition of invasion, and suppression of osteoclastogenesis. Mol Cancer Ther 7: 3306-3317

26. Parasramka MA, Gupta SV (2011) Garcinol inhibits cell proliferation and promotes apoptosis in pancreatic adenocarcinoma cells. Nutr Cancer 63: 456465.

27. Li F, Shanmugam MK, Chen L, Chatterjee S, Basha J, et al. (2013) Garcinol a polyisoprenylated benzophenone modulates multiple proinflammatory signaling cascades leading to the suppression of growth and survival of head and neck carcinoma. Cancer Prev Res 6: 843-854.

28. Saleem M, Afaq F, Adhami VM, Mukhtar H (2004) Lupeol modulates NF-kappaB and PI3K/Akt pathways and inhibits skin cancer in CD-1 mice. Oncogene 23: 5203-5214.

29. Lee JY, Kim JS, Kim JM, Kim N, Jung HC,et al. (2007) Simvastatin inhibits NF-kappaB signaling in intestinal epithelial cells and ameliorates acute murine colitis. Int Immunopharmacol 7: 241-248.

30. Ahn KS, Sethi G, Aggarwal BB (2007) Simvastatin potentiates TNF-alphainduced apoptosis through the down-regulation of NF-kappaB-dependent antiapoptotic gene products: role of IkappaBalpha kinase and TGF-betaactivated kinase-1. J Immunol 178: 2507-2516.

31. Qureshi AA, Tan X, Reis JC, Badr MZ, Papasian CJ, et al. (2011) Suppression of nitric oxide induction and pro-inflammatory cytokines by novel proteasome inhibitors in various experimental models. Lipids Health Dis 10: 177

32. Ahn KS, Sethi G, Chaturvedi MM, Aggarwal BB (2008) Simvastatin 3-hydroxy-3-methylglutaryl coenzyme A reductase inhibitor, suppresses osteoclastogenesis induced by receptor activator of nuclear factor-kappaB ligand through modulation of NF-kappaB pathway. Int J Cancer 123:1733-1740.

33. Liang YJ, Shyu KG, Wang BW, Lai LP (2008) Simvastatin inhibits C-reactive protein-induced pro-inflammatory changes in endothelial cells by decreasing mevalonate pathway products. Cardiology 110: 182-190.

34. Takada Y, Khuri FR, Aggarwal BB (2004) Protein farnesyltransferase inhibito (SCH 66336) abolishes NF-kappaB activation induced by various carcinogens and inflammatory stimuli leading to suppression of NF-kappaB-regulated gene expression and up-regulation of apoptosis. J Biol Chem 279: 26287-26299.

35. Lee DF, Kuo HP, Chen CT, Hsu JM, Chou CK, et al. (2007) IKK beta suppression of TSC1 links inflammation and tumor angiogenesis via the mTOR pathway. Cell 130: 440-455. 